\title{
JOURNAL.RU
}

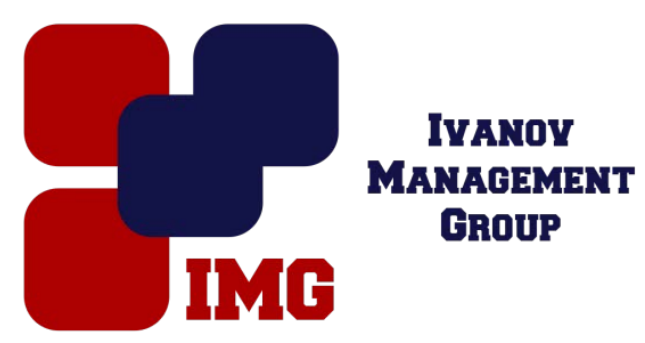

Афанасова О.С. ФГБОУ ВПО «Государственный университет управления» Москва, Россия

doi: 10.18411/lj-30-11-2016-2-02

idsp 000001:lj-30-11-2016-2-02

\section{Учет и налогообложение подарков сотрудникам}

\section{Аннотация}

В данной статье описан порядок учета и налогообложения НДФЛ, НДС стоимости подарков, выданных сотрудникам и их детям. Также описанпорядок включения стоимости подарков в расходы по налогу на прибыль при упрощенной системе налогообложения.

Ключевые слова: подарки сотрудникам, подарки детям сотрудников, налогообложение подарков, НДФЛ, взносы, НДС с подарков, расходы на подарки, подарки, не связанные с трудовой деятельностью.

Приближаются новогодние праздники - пора подарков, премийи благодарностей по итогам года. Одарить сотрудника подарком - один из способов поощрения, награждения, проявления внимания, мотивации. На многих предприятиях подарки являются важной частью корпоративной культуры.

На деле все просто. Наступил праздник, предприятием закуплены или произведены подарки, которые в дальнейшем перешли в руки одариваемых сотрудников. Но для бухгалтеров, озадаченных подготовкой к годовому отчету, подарочные выплаты становятся «головной болью» в виде трех налогов: НДФЛ, взносы во внебюджетные фонды и НДС.

Для того чтобы подробнее разобраться в порядке налогообложения подарков сотрудникам, следует представить классификацию подарков с точки зрения законодательства.

1. Подарки, не связанные с трудовой деятельностью. К таковым относят подарки к памятным датам, праздникам. Стоимость и размер подарка не ограничивается результативностью работы сотрудника и, как правило, не преследует мотивирующую функцию. Основная цель подобных подарков уделить сотрудникам внимание в общечеловеческом понимании. 
Такие подарки производятся в силу положений Гражданского кодекса на основе договора дарения. И речь идет не только о подарке, имеющем вещественную форму. Даже сумму денег можно подарить в рамках гражданского законодательства. Договором дарения предусмотрена передача имущества на безвозмездной основе (ст.572 ГК РФ).

Договор дарения может заключаться в устной форме, если стоимость подарка не превышает 3000 руб., а дарителем выступает юридическое лицо. Далее мы узнаем, почему предприятию безопаснее заключать договор дарения в письменной форме.

2. Подарки, связанные с трудовой деятельностью. К таковым относят подарки за победы в профессиональных конкурсах, за достижение эффективности и результатов труда и в других подобных случаях. Данный вид подарков квалифицируется Трудовым кодексом как поощрение за труд (ст. 191 ТК РФ). И передача подарка производится не по договору дарения, а в рамках трудового контракта. Следовательно, стоимость подарка будет облагаться налогами по правилам налогообложения производственных премий.

В п.28 ст.217 НК РФ сказано, что стоимость подарка в натуральной или в денежной форме облагается налогом на доходы в физических лиц. При этом налогообложение производится на сумму, превышающую 4000 руб. Данное ограничение распространяется на все виды подарков, выданных сотруднику в течение календарного года. Так у сотрудников щедрого работодателя, скорее всего, к новому году лимит в 4000 рублей будет исчерпан. Ставка налогообложения НДФЛ при одаривании сотрудников стандартная - $13 \%$.

Пример. Сотрудникам предприятия вылдан подарок $\kappa$ новому году коробка шоколадных конфет, подарочный сувенир и бутылка шампанского. Общая стоимость подарка - 5500 руб. В течение года сотрудники не получали подарков.

Сумма НДФЛ = (5500 руб. - 4000 руб.) $x$ 13\% = 195 руб.

Порядок обложения взносами на обязательное социальное страхование регулируется Федеральным законом №212-Ф3 от 24.07.2009, в соответствии с которым объектом начисления взносов являются выплаты и вознаграждения в рамках трудовых отношений и гражданско-правовых договоров, предметом которых является выполнение работ, оказание услуг.

С 1 января 2017 года регулирование уплаты страховых взносов будет производиться Налоговым кодексом РФ. Тем не менее, в соответствии со ст.420 новой редакции Налогового кодекса, формулировка объекта обложения страховыми взносами остается прежней.

В соответствии со ст.146 НК РФ передача имущества на безвозмездной основе является объектом налогообложения НДС. Следовательно, при передаче подарков сотрудникам предприятию на общей системе налогообложения необходимо начислить НДС на стоимость подарка. «Входящий» НДС с расходов на приобретение или изготовление подарка можно законно учесть в составе вычетов, уменьшив налогооблагаемую базу. 
Исключение составляют подарки, выдаваемые за трудовые показатели в силу прямого постановления судов (ФАС Центрального округа и ФАС Уральского округа), а также подарки, выданные в денежной форме.

В соответствии со ст.252 НК РФ расходами являются обоснованные и документально подтвержденные расходы. Под обоснованными расходами понимаются экономически оправданные затраты. Данной логики придерживаются и при исчислении УСН.

Таким образом, в составе расходов по УСН и налогу на прибыль можно учесть стоимость только тех подарков, которые связаны с трудовой деятельностью сотрудника. Стоимость подарков к праздникам и памятным датам в составе расходов не учитываются.

Многие организации дарят подаркине только своим сотрудникам, а также и их детям. К таким подаркам относятся сладкие наборы, игрушки или пригласительные билеты на новогодний утренник. В подобной ситуации вопрос о начислении социальных взносов не стоит, поскольку:

- дети сотрудников не являются застрахованными работодателем в системе обязательного социального страхования;

- предприятие и ребенок сотрудника не связаны трудовыми отношениями.

Данное положение справедливо только для социальных взносов, а для целей исчисления НДФЛ применяются все те же положения п.28 ст.217 НК РФ. T.e. при получении ребенком подарка стоимостью менее 4000 рублей необходимости исчисления НДФЛ не возникает.

Для систематизации всех положений по налогообложению подарков разработана таблица 1.

Таблий 1.

Налогообложение подарков сотрудникам

\begin{tabular}{|c|c|c|c|}
\hline Виды налогов и взносов & $\begin{array}{c}\text { Подарок к памятным } \\
\text { датам и праздникам }\end{array}$ & $\begin{array}{c}\text { Подарок, связанный с } \\
\text { трудовой деятельностью }\end{array}$ & $\begin{array}{c}\text { Подарок детям } \\
\text { сотрудников }\end{array}$ \\
\hline НДФЛ & $\begin{array}{c}\text { Начисляется на сумму } \\
\text { свыше 4000 руб. }\end{array}$ & $\begin{array}{c}\text { Начисляется на сумму } \\
\text { свыше 4000 руб. }\end{array}$ & $\begin{array}{c}\text { Начисляется на сумму } \\
\text { свыше 4000 руб. }\end{array}$ \\
\hline Взносы & Не начисляются & Начисляются & Не начисляются \\
\hline Налог на прибыль, УСН & $\begin{array}{c}\text { Не учитывается в } \\
\text { расходах }\end{array}$ & $\begin{array}{c}\text { Уменьшают } \\
\text { налогооблагаемую базу }\end{array}$ & $\begin{array}{c}\text { Не учитывается в } \\
\text { расходах }\end{array}$ \\
\hline НДС & Начисляется & Не начисляется & Начисляется \\
\hline
\end{tabular}

Рассмотрим порядок отражения операций по выдаче подарков на счетах бухгалтерского учета.

Таблий 2.

Корреспонденция счетов бухгалтерского учета по выдаче подарков сотрудникам

\begin{tabular}{|l|c|c|c|}
\hline Содержание операции & Дебет & Кредит & Сумма, руб. \\
\hline Произведена закупка подарков для сотрудников & 10 & 60 & $50000=$ \\
\hline $\begin{array}{l}\text { Начислен входящий НДС со стоимость } \\
\text { подарков }\end{array}$ & 19 & 60 & $9000=$ \\
\hline $\begin{array}{l}\text { Входящий НДС принят к вычету на основе } \\
\text { правильно составленного счет-фактуры }\end{array}$ & 68 & 19 & $9000=$ \\
\hline $\begin{array}{l}\text { Выдан сотруднику Петрову подарок } \\
\text { стоимостью 4500 руб. }\end{array}$ & 73 & 10 & $4500=$ \\
\hline
\end{tabular}




\begin{tabular}{|l|c|c|c|}
\hline $\begin{array}{l}\text { Стоимость подарка, выданного Петрову, учтена } \\
\text { в составе прочих расходов }\end{array}$ & $91 / 2$ & 73 & $4500=$ \\
\hline $\begin{array}{l}\text { Начислен и удержан НДФЛ со стоимости } \\
\text { подарка, превышающего 4000 руб. } \\
(4500 \text { руб. }-4000 \text { руб.) х 13\% }\end{array}$ & 70 & 68 & $65=$ \\
\hline $\begin{array}{l}\text { Начислен НДС со стоимости подарка, } \\
\text { переданнго Петрову } \\
4500 \text { руб. х } 18 \%\end{array}$ & $91 / 2$ & 68 & $810=$ \\
\hline
\end{tabular}

Итак, работодатель, желающий одарить своего сотрудника подарком к новому году, в первую очередь должен позаботиться о правильности оформления и порядке исчисления налогов с подарков. 


\section{Литература}

1. "Гражданский кодекс Российской Федерации (часть вторая)" от 26.01.1996 N 14-Ф3 (ред. от 23.05.2016).

2. "Налоговый кодекс Российской Федерации (часть вторая)" от 05.08.2000 N 117-ФЗ (ред. от 03.07.2016) (с изм. и доп., вступ. в силу с 01.10.2016).

3. "Трудовой кодекс Российской Федерации" от 30.12.2001 N 197-Ф3 (ред. от 03.07.2016) (с изм. и доп., вступ. в силу с 03.10.2016).

4. Федеральный закон от 24.07.2009 N 212-Ф3 (ред. от 03.07.2016) "О страховых взносах в Пенсионный фонд Российской Федерации, Фонд социального страхования Российской Федерации, Федеральный фонд обязательного медицинского страхования".

5. Приказ Минфина РФ от $31.10 .2000 \mathrm{~N}$ 94н (ред. от 08.11.2010) "Об утверждении Плана счетов бухгалтерского учета финансовохозяйственной деятельности организаций и Инструкции по его применению".

6. <Письмо > ФНС России от 22.08.2014 N CA-4-7/16692 <О применении отдельных положений Постановления Пленума ВАС РФ от 30.07.2013 N 57 "О некоторых вопросах, возникающих при применении арбитражными судами части первой Налогового кодекса Российской Федерации">.

7. Письмо Минздравсоцразвития РФ от 27.02.2010 N 406-19<Обложение страховыми взносами отдельных выплат $>$.

8. Письмо Минздравсоцразвития РФ от 05.03.2010 N 473-19<Об уплате страховых взносов со стоимости подарков сотрудникам>.

9. Вопрос: О признании передачи подарков работникам организации объектом налогообложения по НДС (Письмо Минфина РФ от $22.01 .2009 \mathrm{~N}$ 03-07-11/16).

10.Постановление ФАС Центрального округа от 02.06.2009 по делу N A62$5424 / 2008$.

11.Постановление ФАС Уральского округа от 19.01.2010 N Ф09-10766/09-С2 по делу N А07-633/2009. 